\title{
CURRENT PROBLEMS OF BASKETBALL IN THE SYSTEM OF BULGARIAN UNIVERSITY EDUCATION
}

\author{
A. Dimitrova*, V. Dimitrov \\ National Sports Academy „Vassil Levski “, Sofia, Bulgaria
}

\begin{abstract}
The scientific report deals with problems in the Bulgarian university education system and development opportunities at the regional level. The purpose of the research is to reveal some aspects related to the basic forms of physical exercise classes of students and organized independent classes in extra-curricular basketball time in the system of Bulgarian university education. Opportunities offered for integration and employment subsequently. In order to solve the main tasks, achieve the goal and prove the hypotheses, a complex methodology of literature research, observation and discussions are included. A questionnaire was specially designed and developed. The subject of this study is students from three universities in Bulgaria. On the basis of a thorough analysis of qualitative and quantitative data related to the educational process and basketball meetings between different universities, the attitude to the educational process is analysed, various aspects of the activities are analysed and practical measures for improving the preparation of students are outlined. Conclusion: Knowledge and creative mastery of knowledge in this field of science and their application in practice changes in a positive direction the physical development and capacity, and as a result, the health status and academic and working performance of students.
\end{abstract}

Key words: sport, sociology, socialization, employment.

\section{INTRODUCTION}

University sports in Bulgaria have undergone many changes since 1990 . They are the result of political, economic and social factors, which subsequently reflected on the development of physical education and sports. The change of the principle of governance from public-state to a state-public system also has its impact on sports. Leisure sports, children's and youth sports, high-achievement sports and, of course, physical education in schools, including universities, were affected. Effective management until 1990 is the reason for the impressive results achieved by Bulgarian students at prestigious forums: Olympic Games, world, European and national championships. After 1992, university sports began to give way. Students register lower indicators of motor activity and competitive achievements.

\footnotetext{
*Correspondence to: Albena Dimitrova, National Sports Academy ,, Vassil Levski “, 1700, Sofia, Studentski grad, e-mail: albena_dimitrova.nsa@abv.bg, Mobile: +359893396370
}

Adding to this the action of a number of environmental and stress factors accompanying the changes in our society, this may explain the growing psychophysical disharmony and hypo dynamics of Bulgarian students. This harms not only the individual and the universities, but also the state, as it creates staff with poor training and capacity.

The listed social problems are a consequence of contradictions between the needs and the means for their satisfaction, which in public life manifests itself as a contradiction between the actual and desired state. Therefore, social problematization is not at the stage of awareness and definition of the problem situation, but at the stage of elaboration, planning of the problem solution and its solution through organized activity (1).

This phase finds its natural continuation and expression in the national strategy for the development of physical education and sports for the period 2012 - 2022 (2), as well as the National Program for the development of physical education and sports 2018 - 2020 (3). 
The listed official documents concern the integration of physical education and sports in the reconstruction of our educational system. Another emphasis is on building organizational, material, technical and personnel prerequisites for improving the level of sportsmanship in universities, without combining compulsory sports training and competitive student sports. An important part of the national strategy is the organization of mass events and last but not least, the provision of funding for sports activities. This is the influence of sports, including basketball on education as a major social institution.

In connection with the clarification of the multifaceted nature of the issues under consideration, it is necessary to make a reference to the main areas of public life (Table 1).

Table 1. Main areas of public life (Mihaylov, 1981)

\begin{tabular}{ll}
\hline Basic spheres & Chief areas \\
\hline Material production & $\begin{array}{l}\text { Production of material goods } \\
\text { Exchange }\end{array}$ \\
Spiritual production & $\begin{array}{l}\text { Science } \\
\text { Evaluation and regulatory management }\end{array}$ \\
Reproduction of people & $\begin{array}{l}\text { Healthcare } \\
\text { Physical culture and sports } \\
\text { Education and upbringing } \\
\text { Coordinating people's activities } \\
\text { Public management }\end{array}$ \\
\hline Communications & $\begin{array}{l}\text { Exchange of information } \\
\text { Transportation of people and things }\end{array}$ \\
\hline
\end{tabular}

The independent development and functioning of each main area means that it interacts holistically, qualitatively delimited not only within its own main sphere but also with the main areas that are in the other main spheres of public life (5).

The sports reality encompasses structures formed on the basis of the separate, independent "pure" sports activity, as well as structures formed on the basis of activities related to sports, generated and substantiated by it. This wide variety of mixed structures results from the interaction of sport with other major social institutions - family, education, economics, politics, religion and mass communications.

Education is a basic social institution through which the transmission of cultural heritage (professional knowledge and skills, moral values, etc.) from one generation to another, socializes the individual and prepares him for the mastery of various social roles (6), including basketball as a university discipline nationwide.

The social institute "education" influences sports by participating in the processes of socialization to sports through sports programs, and they in turn represent a necessary part of education in modern society.
The main goals of sports programs are: the awareness of the human body as a somatic capital that has expressive and instrumental value; socialization to sport as a social activity through: the perception of participation in systematic sports activities and sports competitions as a personal social value; assimilation of agony, as a normative model of behaviour and assimilation of the cultural norm for fair play, as a socially just model of social interaction and others (7-9).

In order to be able to fully use the basketball game as a means of preserving and improving the health of students, to improve individual basketball skills and improve the level of motor skills, many unresolved pedagogical questions related to the training and organization of classes should be answered, basketball in high schools in order to optimize them.

\section{Hypotheses:}

$>$ we assume that in the course of the research various problems and variations will be revealed, related to the main forms of physical exercise classes for students and organized independent extracurricular basketball lessons in the system of Bulgarian university education;

$>$ we assume that the scientific development will contribute to the enrichment of 
theoretical and practical knowledge, to improve the organization and conduct of basketball classes in higher education in the Republic of Bulgaria.

The aim of the research is to reveal some aspects related to the main forms of physical education classes for students and organized independent extracurricular basketball lessons in the system of Bulgarian university education. Opportunities offered for integration and subsequent employment.

The following main tasks derive from the set goal:

$>$ to reveal and analyse interpretations and variations related to the main forms of classes with physical exercises of students and organized independent classes in extracurricular time in basketball in the system of Bulgarian university education;

$>$ to draw conclusions and recommendations for the theory and practice of sports activities, in order to increase the mass in basketball initiatives and improve sports activities in general.

The subject of the research is problems related to the main forms of physical exercises in basketball in the system of Bulgarian university education.

The object of the study are a total of 300 students from the National Sports Academy "Vassil Levski", Sofia, University of Veliko Tarnovo "St. St. Cyril and Methodius", Veliko Tarnovo and South-western University "Neofit Rilski", Blagoevgrad - 30\% women and 70\% men. The age of the respondents varies, with the predominant part (57\%) being from 18 to 23 years old, and the rest are distributed as follows - 39\% between $24-29$ years and 4\% between the ages of $30-35$ years.

\section{METHODS}

To solve the main tasks, achieve the goal and prove the hypotheses, a complex methodology of research of literature sources, included observation and talks is applied. A specially developed questionnaire for students from the three Bulgarian universities was used and it is anonymous and contains 22 questions (open and closed).

Methodology of the sample in the survey. Students from different courses and specialties were studied, and the selection of respondents is random.
The research was conducted in the period from September 2015 to February 2019.

\section{RESULTS}

The data were subjected to mathematical and statistical processing using the program SPSS 19. The results obtained were processed by variation and frequency analysis, calculation of absolute and relative frequency with onedimensional distribution of data (10-12).

Based on expert assessment in the analysis of the results we focus on some key aspects related to the main forms of physical education classes for students and organized individual extracurricular activities in basketball in the system of Bulgarian university education.

The teaching and education of physical education in higher education institutions is at a higher level than in the school level, as students have a higher level of awareness and ability to work independently, they are socially mature individuals and have a higher level of preparation achieved in school, sports schools, sports clubs, etc. This allows the ultimate goal of the ongoing learning process to be not only an immediate impact, but also to develop students' skills for independent physical education.

The form of the lesson is a definite, purposeful organization of the educational activity and conditions for effective application of the specific means and methods of physical education in accordance with the pedagogical requirements. The main forms of classes with students are the lesson and the training session. As a teaching activity, they are included in the curricula of higher education institutions (13). At the same time, individual classes are held in extracurricular activities.

The learning process is unified in all its diversity. It is carried out in a bilateral interaction between the teacher, who conducts and manages the purposeful pedagogical impact on the students in the process of the specific work activity - learning.

The learning process is a social system with certain goals and objectives, which functions systematically, is aimed at teaching and learning, training and improving motor skills and habits, raising the intellectual level and building moral and ethical virtues. In this process the student has the opportunity not 
only to determine their place, but also to assess their physical development, training, opportunities, etc. among the student community, study and apply in practice the basic laws and principles that lead to the development of its theoretical, physical, technical and mental abilities.

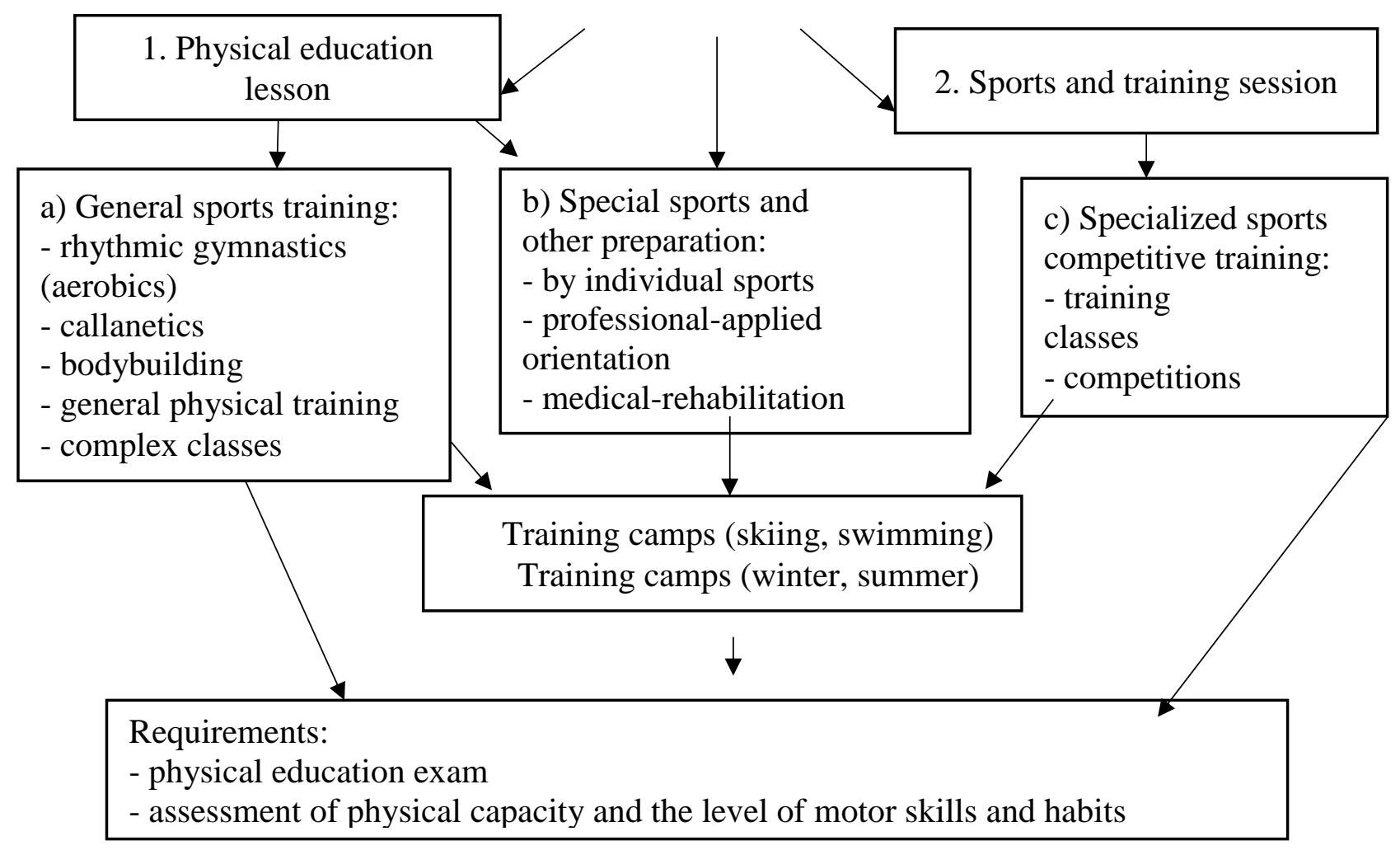

Figure 1. Basic forms of classes for students with physical exercises

Basketball meets the necessary basic requirements for the formation and improvement of any sport. In parallel, detailed, specific training programs are developed for different levels of application (school, university, sports club, children's schools).

"Knowledge of the age and gender characteristics of children is a prerequisite for the sports educator to manage the various stages of long-term sports training. Permanent control over the level of development of the basic motor skills and allows trainers to determine the main directions for optimizing the training process and to work more effectively to develop specific technical and tactical skills" (14).

"Physical activity is an essential element and criterion for a healthy lifestyle" (15), including for people with disabilities and people with different levels of functionality. "Joint sport supports the development of attitudes towards the acceptance of individual differences, protects the right of access to an active lifestyle and sport, and promotes innovative joint programs and systems that lead to the personal growth of all athletes" (16).

When analyzing the results of the survey, it was found that basketball in the system of Bulgarian university education is present as a lesson in the respective higher education institution according to $61 \%$ of respondents, and according to the remaining $39 \%$ of respondents - no.

In SWU "Neofit Rilski" there is a mandatory course "Sport" in the curriculum for the specialty "Physical Education and Sports", and for the other types of specialties there is an opportunity to choose a particular sport.

In VTU "St. St. Cyril and Methodius" students majoring in "Pedagogy of Physical Education" have compulsory basketball training.

In NSA "Vassil Levski" basketball is mandatory for all second year students, regardless of the specialty they study. 
As the frequency of the presence of basketball in the curricula, variations in the answers are also observed: not present (27\%), from 1 to 2 times a week $(63 \%)$ and from 3 to 4 times a week $(10 \%)$.

There are 240 sports classes in higher education institutions that students must cover during their studies for the bachelor's degree. It turns out that the hours of physical education are interpreted differently. By law, sports classes are 60 per year. At the University of Veliko Tarnovo this standard is taken twice a week for the first two years.
DIMITROVA A., et al.

$63 \%$ of the higher education institutions do not meet the requirement of ZFVS for a minimum number of compulsory classes in FVS of 60 teaching hours per year for students who are studying to obtain the educational qualification degree "Bachelor". In almost 90\% of the Universities in Bulgaria there are no FVS classes for the educational qualification degree "Master", i.e. they do not comply with the requirement of the FVS for a minimum working time of compulsory FVS classes of 60 hours per year (17).

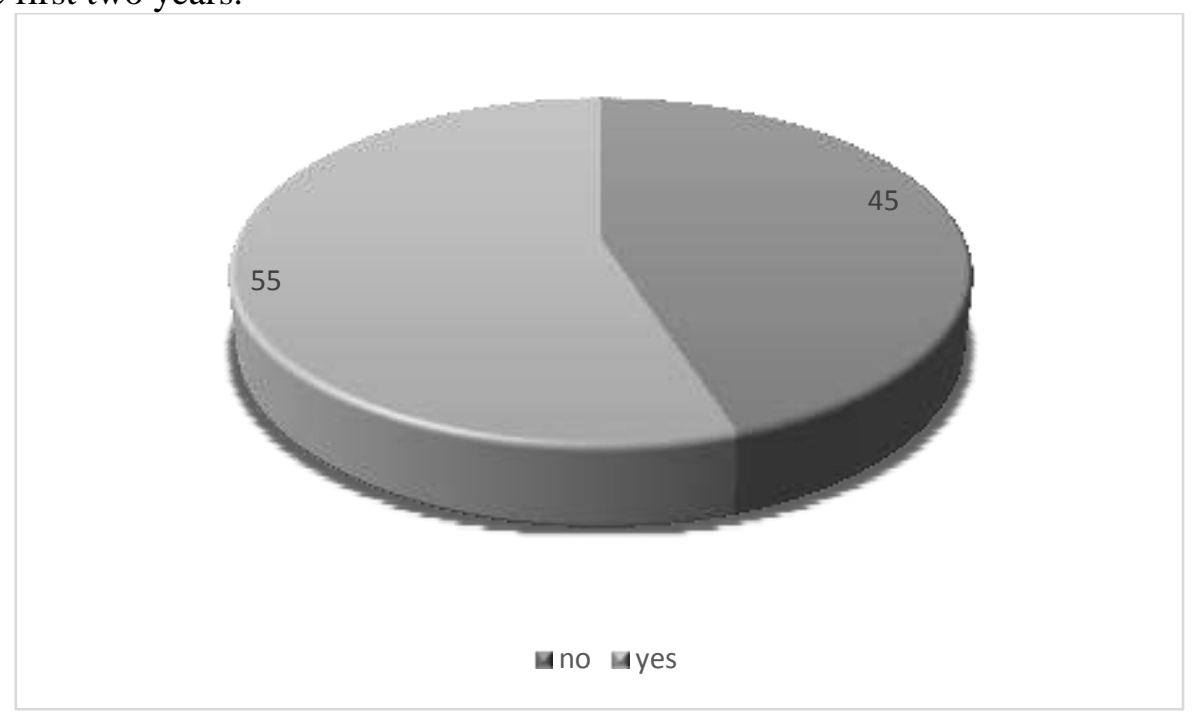

Figure 2. Do you have theoretical basketball classes at your university? (In \%)

The surveyed students state the fact that only in some of the universities in the sample have theoretical classes in the specialized sport of basketball - 55\% and they are held once a week. In its essence it is a generalized and systematized set of reliable, theoretical knowledge (principles, methods) about the patterns of the processes in the training in the basketball game, the training methodology, as well as the emergence and development of the game.

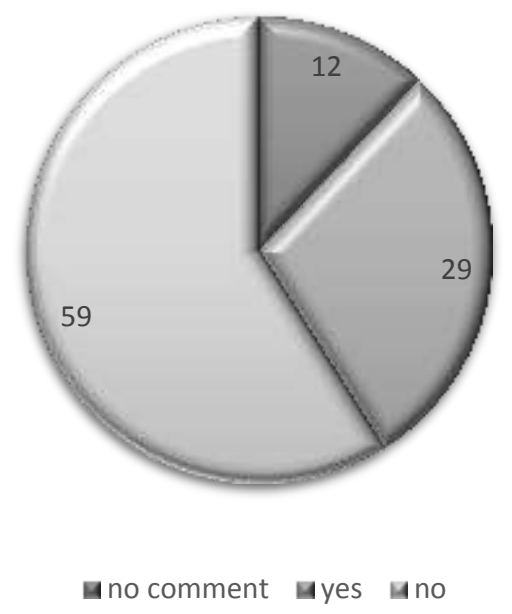

Figure 3. If you have theoretical basketball lessons do you think they are enough? (In \%) 
The data in Figure 3 eloquently show the insufficient number of theoretical basketball lessons $(59 \%)$. $29 \%$ of the respondents who took part in the research believe that they are sufficient. In order to improve the professional qualification of the sports-pedagogical staff, it is necessary to increase the theoretical hours, including both lecture material for general motor activity and specialized lectures given by specialists in the field.

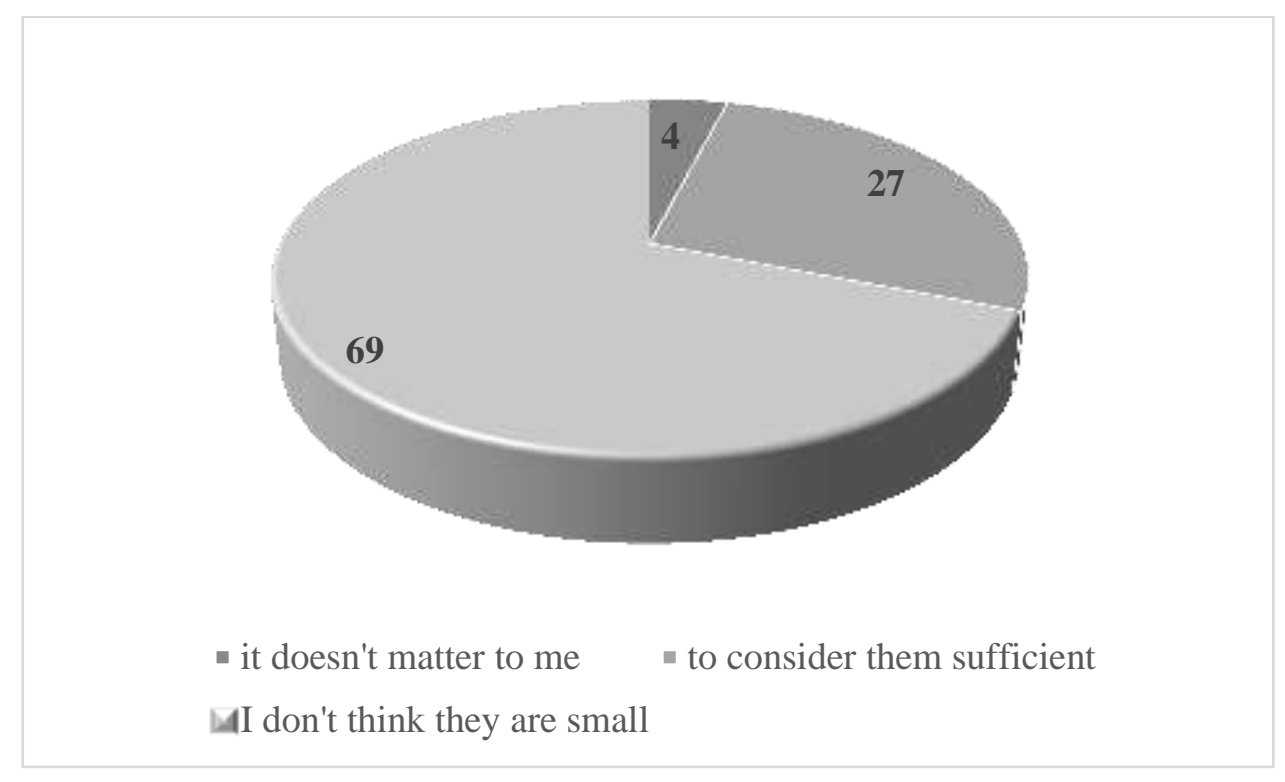

Figure 4. Do you think that your practical basketball lessons are sufficient in the conditions of university education? (in \%)

The answer "No, I think they are few" is ranked first $-69 \%$. Secondly, according to the frequency of responses $(27 \%)$ are of the opposite opinion and for $4 \%$ it does not matter (Figure 4). Basketball assumes on the basis of the studied technical techniques, students to achieve high efficiency in performing technical and tactical tasks in the training process and in competition, mastering individual and participation in team tactical actions in the game, demonstrating their own style of play in the competition and increase physical development.

The practical basketball class at the three universities studied is attended once a week. In higher education, the discipline "Sport" provides students with the opportunity to develop practical skills in selected sports and theoretical knowledge needed to build their own physical education, organization of a healthy lifestyle and health promotion.

To the question "Are there additional basketball classes to improve basketball training at your university?" Only $25 \%$ of students answered positively and $75 \%$ negatively.
$59 \%$ of the respondents did not participate in student championships / basketball matches, and $41 \%$ participated in various other sports events.

The fact that students from specialized groups do not prepare for participation in competitions significantly changes the purpose of basketball education at universities. Adding the small number of training hours provided in the students' schedules establishes the need to create a specialized model for teaching basketball to students. An exception is NSA "Vassil Levski", which offers training as a coach in sports (including basketball) with an entrance exam.

To the question "Under what conditions do your basketball lessons take place?", The majority of the participants in the survey $(80 \%)$ believe that the material bases and conditions in them are at a low level. There is a lack of equipment, the playing field is of poor quality, as the indoor sports facilities are few in number and this limits the practice of sports during the winter. Another downside is the outdoor sports fields, as most of them are located in unlit places and lack sports facilities. A smaller part of the respondents (20\%) indicated that the conditions for conducting 
basketball classes are performed mainly in halls with the necessary equipment, good terrain and auxiliary materials for the game.

"What do you think needs to change in order for basketball to be a more attractive and popular sport in the context of university education?" Respondents are unanimous marketing and advertising of the sport. Basketball needs to be promoted and offered to students because "sport as a social phenomenon stimulates the good health and well-being of society; creates an environment for learning and socialization; makes a fundamental contribution to the development of democratic societies; contributes to the implementation of the principles of tolerance and increases its role in the economies of the countries" (18).

The development of the basketball game is constantly expanding its boundaries. It has reached incredible business dimensions worldwide and has become a powerful social factor. Its development on a national scale will continue incredibly, but it is expected that this will happen at a slow pace, even when it comes to innovations, technologies and changes in the rules of the game.

"The use of modern technology in sport can lead to greater speed and flexibility in the processing of large amounts of information and thus help to better plan the organization of sport" (19).

Today, a trend in the development of higher education is the large mismatch between the growing demands of students' learning activities, their mental and physical abilities and the constant decrease in physical activity and physical capacity, and ultimately to the continuous increase in hypo dynamics and morbidity. The existing curricula for physical education in higher education do not correspond to the new requirements and realities (20). The conscious public interest is reflected in the goals, plans and programs of activity. It is inseparable from activity, and activity without interest is impossible (21).

\section{CONCLUSIONS}

Various problems and variations were revealed, related to the main forms of classes with physical exercises of students and organized independent classes in extracurricular time in basketball in the system of the Bulgarian university education.
Theoretical and practical basketball lessons in higher education are not enough. There are no additional basketball lessons. The material base, equipment and sports facilities for basketball practice are not at a good enough level. It is necessary to purposefully provide students with access to specialized facilities and training facilities in order to provide better conditions.

Students believe that basketball can become a more attractive and popular sport if: additional theoretical and practical classes are introduced; increase the interest of teenagers in this sport and promote it more often on social networks, media and posting posters in appropriate and accessible places.

To increase the socio-economic significance of basketball in Bulgaria, it is necessary that the policy and strategy of the Bulgarian Basketball Federation be oriented towards improving the organizational, managerial, personnel, methodological, logistical, informational and financial provision in higher education institutions.

MES, MMC and BSE need to work together to improve the educational and sportscompetitive process of students in the Republic of Bulgaria.

In order to increase the level of sports and in particular basketball for high achievements and raising the prestige of Bulgarian sports, it is necessary to increase the role of scientific and applied activities in sports, which will support the implementation of scientific and methodological control and assistance to coaches in preparing students for participation in competitions.

The summarized conclusions give us reason to conclude that the purpose and objectives of the study are fulfilled, and the main working hypotheses are confirmed.

The knowledge and creative mastering of the knowledge in this field of science and their application in practice changes in a positive direction the physical development and the legal capacity, and as a result the health condition and the academic and labour success of the students.

\section{REFERENCES}

1. Dimitrov, R., Problem, sotsialen. In: Entsiklopedichen rechnik po sotsiologia, 
Vtoro izdanie, BAN, Izd. „M-8-M “, Sofia, pp. 353, 1997.

2. Natsionalna strategia za razvitie na fizicheskoto vazpitanie i sporta $\mathrm{v}$ Republika Bulgaria 2012-2022 g.

3. Natsionalna programa za razvitie na fizicheskoto vazpitanie i sporta 2018 2020.

4. Mihaylov, St., Sotsiologicheski studii. Sofia, pp. 66, 1981.

5. Angelov, A., Gosheva, M., Uchebnik zapiski po sotsiologia na sporta. Sofia: VIF „GEORGI DIMITROV “, pp. 3 - 19, 1979.

6. Lubisheva, L. Sotsiologia fizicheskoy kulyturi i sporta. Uchebno posobie, Moskva, ACADEMA, pp. 234, 2004.

7. Tsonev, St., Kategoriyata sport v refleksivnata sotsiologia. In: Sport i nauka, 7, $43-48,1993$.

8. Tsonev, St., Motivatsiyata na sportista sotsiologichesko obyasnenie. In: Sport $i$ nauka, 8 (priturka), 38 - 41, 1995.

9. Tsonev, St., Sotsialnite subekti v sportnoto prostranstvo. In: Sport i nauka, 10 - 11, 85-91, 1995.

10. Goev, K., Statisticheska obrabotka i analiz na informatsiyata ot sotsiologicheski, marketingovi i politicheski izsledvania sas SPSS, Sofia, Universitetsko izdatelstvo „Stopanstvo “, 1996.

11. Margaritova, V., Sportna statistika, Plovdiv 2002.

12. Gigova, V., Damyanova, R., Statisticheski metodi v sporta, Sofia, NSA PRES, 2012.
13. Ivanov, I. Fizichesko vazpitanie vav VUZ. Teoria i metodika, Sofia, UASG - UIK Izdatelski tsentar, 2000.

14. Borukova, M., Management and control of sports preparation of 14-15-years old female basketball players, Journal of Applied Sports Science, Vol 2, pp. 19-30, 2017.

15. Borukova, M., Factor structure and major factors of physical ability of 13-14 years old, Journal of Applied Sports Science, Vol 1, 2019.

16. Dzhobova, S., M. Borukova. Da igraem zaedno. T. IN. BASKET - Totally Integrated Basketball. In: Sport $i$ nauka, Izvanreden broy 5, pp. 242-251, 2015.

17. Georgiev, Zh., Analiz na sastoyanieto i tendentsii za razvitie na universitetskia sport v Republika Bulgaria. In: Savremenni tendentsii na fizicheskoto vazpitanie i sporta. Sofia: Universitetsko izdatelstvo „Sv. Kliment Ohridski” 2017.

18. Dimitrov, V., Sportno pravo, Sofia: NSA PRESS, pp. 66, 2016.

19. Dimitrov, V., Planirane na choveshkite resursi v sportnata deynost. In: Predizvikatelstva i perspektivi pred sportnata nauka, pp.12-18, 2017.

20. Ivanov, I., Optimizirane na FV vav VUZ, Sofia, 1994.

21. Simeonov, P., Interes. In: Entsiklopedichen rechnik po sotsiologia, Vtoro izdanie, BAN, Sofia, Izd. „M-8-M “, pp. $180-181,1997$. 